\title{
Effect of CPP-ACP on enamel eroded extrinsically: in vitro study
}

\author{
Efeito do CPP-ACP sobre o esmalte erodido extrinsecamente: estudo in vitro
}

landara de Lima SCARDINI ${ }^{1}$

(iD) ORCID iD 0000-0001-8573-211X

Marcella Kretli Neves DIAS ${ }^{1}$

(D) ORCID iD 0000-0003-2990-7485

Martha Chiabai Cupertino de CASTRO²

(iD) ORCID iD 0000-0002-8793-5700

Ana Paula Albuquerque GUEDES ${ }^{2}$

(D) ORCID iD 0000-0003-3514-017X

Letícia Monteiro PEIXOTO²

(iD) ORCID iD 0000-0003-3528-9476

\section{ABSTRACT}

Objective

The aim of this study was to evaluate the remineralization effect of CPP-ACP on tooth enamel that is eroded extrinsically.

\section{Methods}

Sixty freshly extracted bovine teeth were stored in a solution of thymol $(0.1 \%)$, cut into enamel blocks (6x6mm), abraded with silicon carbide sandpaper (600, 800 and 1200 grit) and polished with felt. The specimens were randomly divided into 4 groups ( $n=15)$, varying the immersion medium, deionized water or citric acid, and the optional use of CPP-ACP. (G1: deionized water; G2: citric acid; G3: deionized water + CPP$A C P ;$ G4: citric acid + CPP-ACP). The samples were subjected to 4 cycles of erosion every day, comprising 5 minutes immersion in one medium and 2 hours of immersion in artificial saliva, for 5 consecutive days. After each erosive cycle, 20 uL of the MI Paste was applied for 5 minutes on one half of the samples and washed with deionized water. Before and after the erosive cycling, the measurements of Vickers hardness and surface roughness were taken.

\section{Results}

The results were evaluated through statistical testing. The final hardness and roughness values showed no statistically significant difference between G2 and G4. The paste in G4 did not promote an increase in hardness values nor a decrease in roughness values.

\section{Conclusion}

It was concluded that CPP-ACP was unable to remineralize enamel subjected to extrinsic erosion, being ineffective in preventing erosion of enamel and in the remineralization of the eroded enamel.

Indexing terms: Tooth remineralization. Tooth erosion. Dental enamel.

\section{RESUMO}

\section{Objetivo}

Avaliar o efeito de remineralização do CPP-ACP sobre o esmalte dentário erodido extrinsecamente.

\section{Métodos}

Sessenta dentes bovinos recém-extraídos, foram armazenados em solução de timol 0,1\%, cortados em blocos de esmalte (6x6mm), desgastados com lixas de carbeto de silício $(600,800$ e 1200) e polidos com feltro. Os espécimes foram distribuídos aleatoriamente em 4 grupos ( $n=15)$, variando o meio de imersão, água deionizada ou ácido cítrico; e o uso ou não do CPP-ACP (G1: água deionizada; G2: ácido cítrico; G3: água deionizada + CPP-ACP; G4: ácido cítrico + (PP-ACP). As amostras foram submetidas a 4 ciclos erosivos diários de 5 minutos de imersão em um dos meios e 2 horas de imersão em saliva artificial, durante 5 dias consecutivos. Após cada ciclo erosivo, $20 \mu \mathrm{L}$ da pasta MI Paste foram aplicadas por 5 minutos em metade das amostras e lavadas com água deionizada. Antes e após a ciclagem erosiva as mensurações de dureza Vickers e rugosidade de superfície foram realizadas.

\section{Resultados}

Os resultados foram avaliados através de testes estatísticos. Os valores de microdureza e rugosidade final não apresentaram diferença estatisticamente significante entre os grupos G2 e G4. No G4 a pasta não promoveu aumento nos valores de microdureza e nem diminuição nos valores de rugosidade.

\section{Conclusão}

Concluiu-se que o CPP-ACP não foi capaz de remineralizar o esmalte submetido a erosão extrínseca, sendo ineficaz na prevenção da erosão do esmalte e na remineralização do esmalte erodido.

Termos de indexação: Remineralização dentária. Erosão dentária. Esmalte dentário.

\footnotetext{
${ }^{1}$ Universidade Federal do Espírito Santo, Faculdade de Odontologia. Vitória, ES, Brasil.

${ }^{2}$ Universidade Federal do Espírito Santo, Faculdade de Odontologia, Departamento de Prótese Clinica. Av. Fernando Ferrari, 514, Goiabeiras, 29075910, Vitória, ES, Brasil. Correspondência para / Correspondence to: MCC CASTRO. E-mail: <marthachiabai@hotmail.com>
}

\section{$\mathbf{v} \mathbf{v}$}

Como citar este artigo / How to cite this article

Scardini IL, Dias MKN, Castro MCC, Guedes APA, Peixoto LM. Effect of CPP-ACP on enamel eroded extrinsically: in vitro study. RGO, Rev Gaúch Odontol. 2018;66(1):21-28. http://dx.doi.org/10.1590/1981-863720180001000033193 


\section{INTRODUCTION}

Dental erosion is a new risk factor for oral health, prompted by modern-day lifestyles and eating habits. It is defined as the irreversible loss of dental tissue resulting from frequent and long lasting, non-bacterial, chemical attacks, that is, involving acidic substances of either extrinsic or intrinsic etiology ${ }^{1,2}$. Extrinsic factors, for the most part, include the consumption of acidic foods and carbonated drinks, energy drinks, red and white wine and citric fruit ${ }^{3}$.

With the increased prevalence of dental erosion, greater attention has been paid to investigating the use of remineralizing agents, since several studies have demonstrated that the eroded substrate can be remineralized and that its resistance to abrasion can be improved $^{4-6}$.

Casein, a phosphoprotein found in milk, has been identified as one of the fractions of cow's milk that makes the mineral structure of the tooth more resistant and less soluble to acid attack ${ }^{7}$. Enzymes present in the oral cavity produce peptides from the casein, forming casein phosphopeptides (CPP), responsible for the remineralizing effect of the enamel. CPP has the ability to stabilize the phosphate and the calcium, keeping them in an amorphous or soluble form known as ACP (amorphous calcium and phosphate), providing a reservoir of ions during an acid attack on the tooth surface, saliva and biofilm ${ }^{8}$. It is proposed that a fine layer of this phosphoprotein forming on the surface of the tooth may act as a barrier, restricting the access of hydrogen ions, preventing the loss of calcium and phosphate in the hydroxyapatite crystals $s^{9-11}$.

The inclusion of casein in products which are readily available to the population would have the effect of acting to minimize erosion. A product has been launched on the market, for professional use, the composition of which contains CPP-ACP. According to the manufacturer, MI Paste ${ }^{\circledR}$ (GC Corporation, Tokyo, Japan), it is a water-based paste for topical use containing Recaldent ${ }^{\mathrm{TM}}$ CPP-ACP, a casein derived from milk. When the CPP-ACP is applied to the oral cavity, it bonds with the biofilm, bacteria, hydroxyapatite and the soft tissue, releasing the bioavailable phosphate and calciums ${ }^{11,12}$.

In the literature, there is an element of controversy concerning the effectiveness of CPP-ACP. While some studies have not shown these agents to be particularly favorable with regard to enamel erosion ${ }^{11,13,14}$, other works have been demonstrating an increase in enamel microhardness with the use of CPP-ACP and a protective effect in the demineralization of human tooth enamel under erosive conditions ${ }^{7,15-18}$. Consequently, the need for further studies on the subject is justified.

With the increase in the prevalence of dental erosion and the need for products that remineralize the eroded dental tissue and prevent the progression of lesions, the present study evaluates the effect of casein remineralization (CPP-ACP) on enamel subjected to dental erosion, comparing the values for Vickers hardness and for surface roughness.

\section{METHODS}

\section{Experimental design}

Sixty blocks of bovine enamel, measuring 6 by $6 \mathrm{~mm}$, were divided into 4 groups $(n=15)$ according to the medium used, namely MA (deionized water) and $M B$ (citric acid), and the surface treatment employed, TA (without the use of CPP-ACP) and TB (with the use of (PP-ACP). G1= MA, TA; G2=MB, TA; G3= MA TB; G4= $M B T B$. The samples were subjected to 4 five-minute daily cycles of immersion in one of the media and 2 hours of immersion in artificial saliva, for 5 consecutive days. The MI Paste was applied for 5 minutes after each cycle and the samples were rinsed in deionized water. Before and after the erosive cycling, the variables Vickers hardness and surface roughness were obtained for the different test-specimens. The initial and final hardness and roughness values were used to determine alterations in the bovine substrate.

\section{Sample preparation}

Sixty freshly extracted bovine teeth selected for the study were stored in a solution of thymol $(0.1 \%)$ at $4^{\circ} \mathrm{C}$ for a period of 30 days. Enamel blocks measuring 6 $\mathrm{mm} \times 6 \mathrm{~mm}$ were obtained with the aid of a Labcut 1010 metallographic cutting machine (ERIOS Equipamentos Técnicos e Científicos Ltda., São Paulo, Brazil) and a diamond grinding disc (Extec Corp., Enfield, CT, USA), with low concentration at low speed, and with constant irrigation. With the aim of facilitating the handling of the samples, they were inserted in silicone tubes containing acrylic resin, with the buccal surface of the enamel facing upwards. The test specimens were then abraded using a Metalprisma polisher (ERIOS Equipamentos Técnicos 
e Científicos Ltda., São Paulo, Brazil) and 600, 800 and 1200 grit silicon carbide sandpaper (Extec Corp., Enfield, CT, USA) and subsequently felt polished (Buehler, USA) moistened with diamond pastes $(6,3,1$ and $0.25 \mu \mathrm{m})$ for a period of 4 minutes per phase. In order to ensure the samples remained parallel to the ground and to allow a better reading of the variables analyzed, for each sample a base was fabricated with autopolymerizing acrylic resin on a manual sample press. The samples were cleaned in an ultrasonic tank (Cristófoli, Campo Mourão, Paraná, Brazil) containing deionized water, for 5 minutes, between one sheet of sandpaper and another at the end of the process, in order to avoid residual granulation from the previous sandpaper.

\section{Vickers hardness}

For the evaluation of Vickers microhardness, the test specimens were placed separately in an HMV-2000 Shimadzu Microhardness Tester (Shimadzu Corporation, Kyoto, Japan), under a load of $25 \mathrm{~g}$, for 10 seconds. Three readings were taken for each test specimen and the arithmetic mean was calculated.

\section{Surface roughness}

Surface roughness was analyzed by a Surftest 301 roughness meter (Mitutoyo, Kanagawa, Japan). The roughness standard used was the $\mathrm{Ra}$, which represents the arithmetic mean between the recorded peaks and troughs. A $0.25 \mathrm{~mm}$ cut-off was used, required to maximize the filtration of the surface undulation, and on each surface, three readings were taken at different positions and the arithmetic mean was calculated.

\section{Erosive challenge}

The erosive challenges were carried out in 2 different media: deionized water and citric acid (0.3\%) $(\mathrm{m} / \mathrm{v})$ with a pH of 3.25 (adjusted using sodium hydroxide), at room temperature. The samples were immersed in individual containers, each one containing $25 \mathrm{ml}$ of each solution, at room temperature, for 5 minutes, 4 times a day. The specimens were washed in deionized water and immersed in artificial saliva, pH 7.0 (25 ml/block) at room temperature for 2 hours, between erosive challenges and throughout the night, as proposed by Carvalho et al. ${ }^{11}$. The artificial saliva was made as per the study by Moretto $^{19}$, with the following composition: $1.5 \mathrm{mmol} / \mathrm{l}$ $\mathrm{Ca}(\mathrm{NO} 3) 2 \bullet 4 \mathrm{H} 2 \mathrm{O}, \quad 0.9 \mathrm{mmol} / \mathrm{l} \mathrm{NaH} 2 \mathrm{PO} 4 \bullet 2 \mathrm{H} 2 \mathrm{O}, 150$ $\mathrm{mmol} / \mathrm{l} \mathrm{KCl}, 0.1 \mathrm{~mol} / /$ Tris buffer solution, $0.03 \mathrm{ppm} \mathrm{F,} \mathrm{pH}$
7.0. The erosive challenges were repeated every day for 5 days. The media and artificial saliva were changed after each erosive cycle. During the demineralization cycles, the specimens remained in hermetically sealed containers to prevent the solutions from evaporating.

After each cycle, $20 \mu \mathrm{L}$ of product containing CPP-ACP, MI Paste (GC Corporation, Tokyo, Japan) was applied to the enamel surface of half of the specimens for 5 minutes, in accordance with manufacture's instructions ${ }^{20}$. The samples were washed in deionized water to remove the product.

At the end of the period of the experiment, the test specimens were submitted to new readings of surface roughness and Vickers hardness, as previously described.

\section{Statistical analysis}

The values were submitted to statistical analysis using the following normality tests: Shapiro-Wilk, t-test for means, paired t-test, Mann-Whitney nonparametric test and the Wilcoxon test, with a level of significance of $p<0.05$, using the statistical software programs BioEstat 5.3 and SPSS

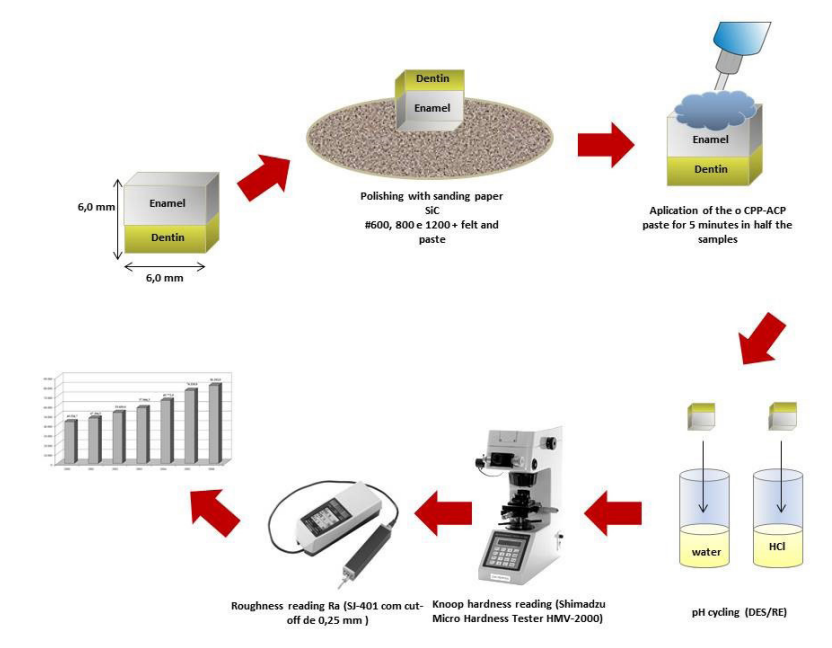

Figure 1. Illustrative diagram of the study methodology.

\section{RESULTS}

\section{Microhardness}

Comparison between groups

The Shapiro-Wilk normality test was applied, observing that the hypothesis of normality was not rejected, thus the t-test for means was applied (Table 1). 
Table 1. Comparison of initial and final microhardness between groups $\mathrm{G} 1$ vs $\mathrm{G} 3$ and $\mathrm{G} 2$ vs G4.

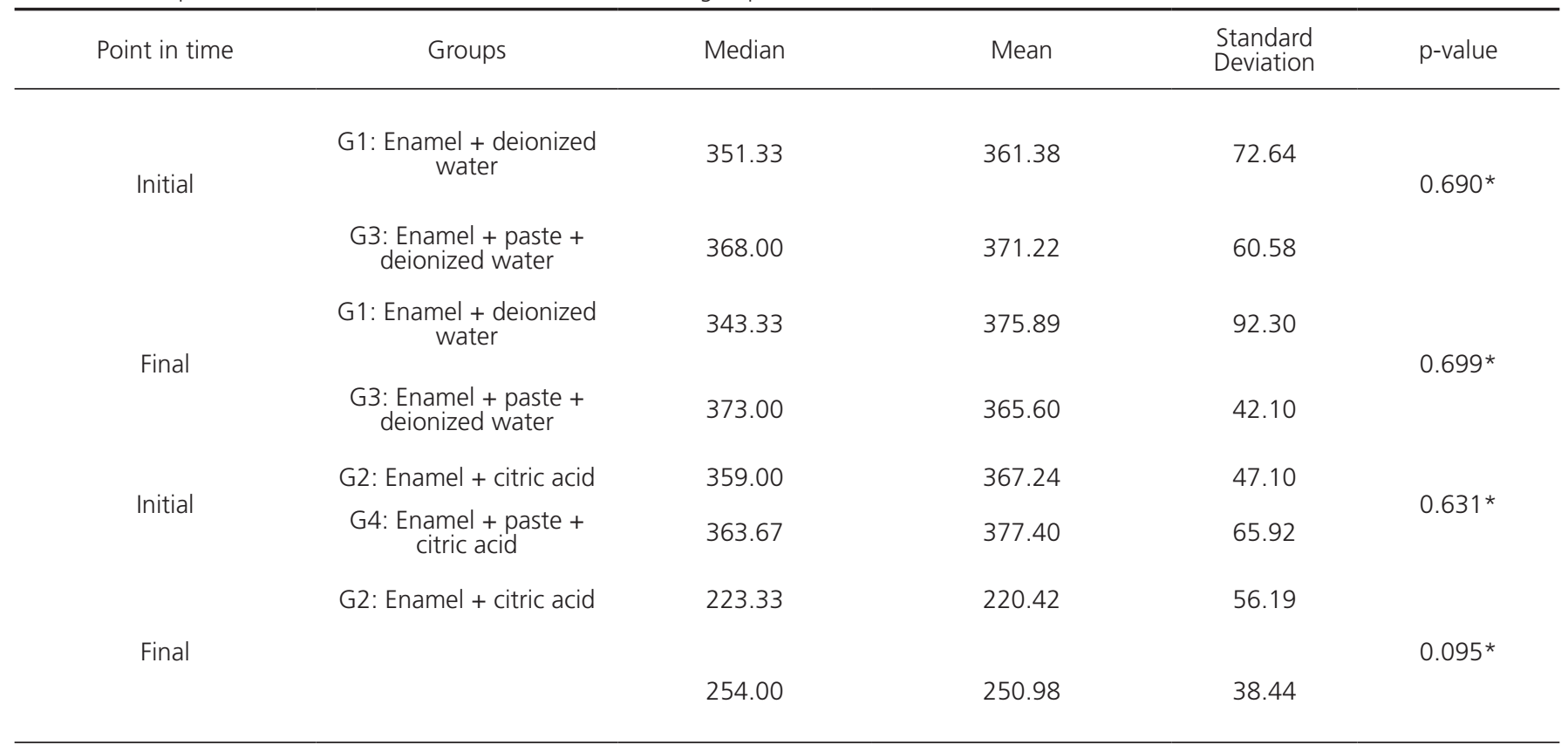

Note: * T-test for means

Comparing the initial and final microhardness values between the groups $\mathrm{G} 1$ vs $\mathrm{G} 3$ and $\mathrm{G} 2$ vs $\mathrm{G} 4$, there was no statistically significant difference between the tested groups in results found.

\section{Comparison between points in time}

Here we have a paired sample, i.e. the measurement of the same test specimen is taken at two distinct points in time. A parametric test was applied - the paired t-test (Table 2).

Table 2. Comparison of microhardness between the initial and final points in time for each group.

\begin{tabular}{|c|c|c|c|c|c|}
\hline Groups & Point in time & Median & Mean & $\begin{array}{l}\text { Standard } \\
\text { Deviation }\end{array}$ & $p$-value \\
\hline \multirow[t]{2}{*}{$\begin{array}{c}\text { G1: Enamel + deionized } \\
\text { water }\end{array}$} & Initial & 351.33 & 361.38 & 72.64 & \multirow{2}{*}{0.664} \\
\hline & Final & 343.33 & 375.89 & 92.30 & \\
\hline G2: Enamel + citric acid & Initial & 359.00 & 367.24 & 47.10 & 0.000 \\
\hline \multirow[t]{2}{*}{$\begin{array}{l}\text { G3: Enamel + paste + } \\
\text { deionized water }\end{array}$} & Initial & 368.00 & 371.22 & 60.58 & \multirow{2}{*}{0.759} \\
\hline & Final & 373.00 & 365.60 & 42.10 & \\
\hline $\begin{array}{l}\text { G4: Enamel + paste + } \\
\text { citric acid }\end{array}$ & Initial & 363.67 & 377.40 & 65.92 & 0.000 \\
\hline
\end{tabular}

In the comparison between the initial and final points in time of each group, a statistically significant difference was found between the two points in time in groups $G 2$ and G4. In these two groups subjected to acid attack, the microhardness values decreased.

\section{Surface roughness}

\section{Comparison between groups}

The Shapiro-Wilk normality test was applied. It was observed that the hypothesis of normality was rejected in 
nearly all the groups. This being the case, the Mann-Whitney nonparametric test was applied (Table 3).

Comparing the initial and final roughness values between the groups $\mathrm{G} 1$ vs $\mathrm{G} 3$ and $\mathrm{G} 2$ vs $\mathrm{G} 4$, there was no statistically significant difference in results between the tested groups.

Table 3. Comparison of initial and final Roughness between groups $\mathrm{G} 1$ vs $\mathrm{G} 3$ and $\mathrm{G} 2$ vs $\mathrm{G} 4$.

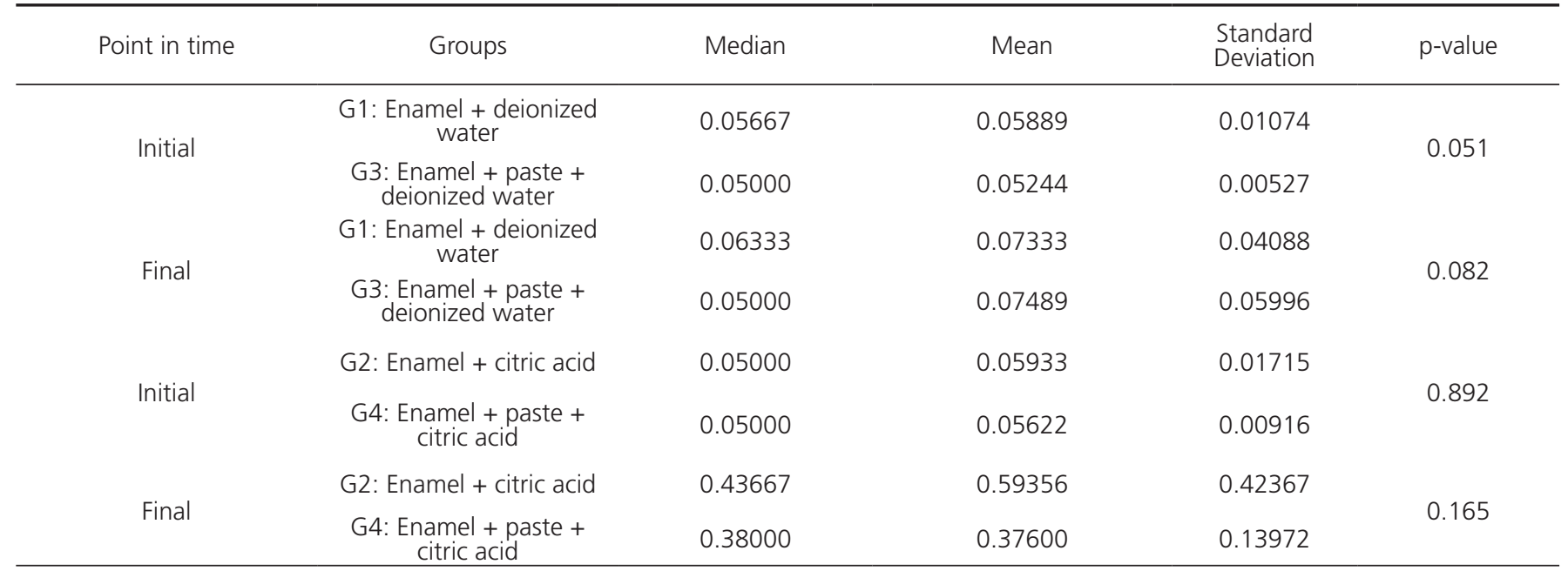

Comparison between moments in time

A nonparametric test was also applied here. Here we have a paired sample, i.e. the measurement is taken on the same test specimen at two different points in time, so the Wilcoxon test was applied (Table 4).
In the comparison between the initial and final points in time in each group, a statistically significant difference was found between the points in time in groups G2 and G4. In these groups, there was an increased roughness with the use of citric acid, that remained in an altered state after the use of the paste.

Table 4. Comparison of roughness between the start and end moments in each group.

\begin{tabular}{|c|c|c|c|c|c|}
\hline Groups & Point in time & Median & Mean & $\begin{array}{l}\text { Standard } \\
\text { Deviation }\end{array}$ & $p$-value \\
\hline \multirow{2}{*}{$\begin{array}{c}\text { G1: Enamel + deionized } \\
\text { water }\end{array}$} & Initial & 0.05667 & 0.05889 & 0.01074 & \multirow{2}{*}{0.362} \\
\hline & Final & 0.06333 & 0.07333 & 0.04088 & \\
\hline G2: Enamel + citric acid & Initial & 0.05000 & 0.05933 & 0.01715 & 0.001 \\
\hline \multirow{2}{*}{$\begin{array}{l}\text { G3: Enamel + paste + } \\
\text { deionized water }\end{array}$} & Initial & 0.05000 & 0.05244 & 0.00527 & \multirow{2}{*}{0.292} \\
\hline & Final & 0.05000 & 0.07489 & 0.05996 & \\
\hline $\begin{array}{l}\text { G4: Enamel + paste + } \\
\text { citric acid }\end{array}$ & Initial & 0.05000 & 0.05622 & 0.00916 & 0.001 \\
\hline
\end{tabular}

\section{DISCUSSION}

In the present study, it was observed that the paste containing CPP-ACP was not capable of preventing mineral dissolution caused by exposure to citric acid, permitting a fall in microhardness values and an increase in surface roughness values similar to the control group, and was, therefore, ineffective in remineralizing the 
enamel subjected to simulated, extrinsic erosion. In addition, it was unable to harden the enamel that was not subjected to acid attack through mineral gain, and did not promote an increase in microhardness values in the positive control group.

The use of toothpaste would be the preferred mode of topical availability of CPP-ACP, as toothpastes are routinely used in oral hygiene. Accordingly, the use of Ml Paste as a toothpaste in the present study is justified ${ }^{21}$. Studies by Wegehaupt \& Attin ${ }^{13}$, Rallan ${ }^{14}$ and Carvalho ${ }^{11}$ which found similar results to our study, used the provision of CPP-ACP through the use of toothpaste, unlike the studies by lijima ${ }^{7}$, Cai et al. ${ }^{15}$, Prestes $^{16}$ and Alencar ${ }^{17}$ in which the CPP-ACP was released on to the enamel with the use of chewing gum, which may explain the difference found in the results. The paste was applied after the erosive challenge with the aim of making the conditions as close as possible to reality, with cleaning performed normally after eating.

In vitro results must be interpreted with caution as mineral dissolution may be influenced by the presence of acquired film in actual clinical conditions ${ }^{22}$. In addition, in the action mechanism of the products derived from milk proteins, the presence of acquired film and plaque is necessary and the process of dental erosion in the initial stages causes a loss of salivary organic substances that cover the tooth surface, i.e. the film ${ }^{23}$. Hence, it is believed that a limitation occurs for the reversal of the process of loss of mineral structure, due to erosion by these products.

In the present study, as in the studies by Wegehaupt \& Attin ${ }^{13}$, Rallan ${ }^{14}$ and Carvalho ${ }^{11}$, there was no biofilm and/or bacterial plaque present, which might have influenced the results, as in all of these studies the CPP-ACP complex was not effective in combating erosion. As for the studies of lijima ${ }^{7}, \mathrm{Cal}^{15}$, Prestes ${ }^{16}$ and Alencar ${ }^{17}$ there was a presence of acquired film and the results for the use of CPP-ACP were favorable.

It is important to stress that the erosive potential in in vitro studies are overestimated and the role of the products underestimated since they do not encompass all intra-oral events ${ }^{24}$. On the other hand, it should be emphasized that the remineralizing action of the saliva in in vivo studies ${ }^{7,15-17}$ could mask the actual effect of the CPP-ACP.

Several authors have shown that different lengths of exposure for acidic beverages result in very different estimates of erosive potential and that the choice of study methodology can affect the results of the study ${ }^{21}$. In the study by Carvalho ${ }^{11}$ the erosive challenge was conducted for five minutes, four times a day for 5 days, similar to the present study, and both produced the same result. The difference in the choice of methodology could explain the difference in the results found between the different studies. Young and Tenuta $^{25}$ in 2011 stated that, in an actual clinical situation, the period of time during which the $\mathrm{pH}$ remains low, is usually no longer than 2 minutes. Thus, the erosive challenge selected for the present study may be considered moderate to intense, which also explains the results found.

The decision was taken to store the fragments of enamel in saliva because the literature maintains that saliva provides better protection against mineral loss through erosion, than when stored in distilled water ${ }^{26}$, as well as the fact that the protective potential of saliva was described in the literature as the most important biological factor in the pathogenesis of dental erosion 27,28 .

Although some research studies have shown that CPP-ACP might be able to control demineralization of enamel and even prevent erosive lesions, its efficacy in a clinical environment is still debatable. In vitro studies, even when well managed, possess certain limitations as they are not carried out in the oral environment and, therefore, do not suffer interference from the medium, for instance from saliva, temperature, microorganisms and enzymes. Moreover, the present study did not perform a comparison between the groups in terms of the quantity of enamel lost after the erosive challenge and, therefore, it is not possible to state with any precision that the groups exhibit the same characteristics.

\section{CONCLUSION}

Based on the results obtained, it may be concluded that the use of toothpaste containing CPP-ACP was not capable of preventing erosion of the enamel and the increase in roughness caused by exposure to citric acid. Although the use of paste containing CPP-ACP seems promising, there is still insufficient scientific evidence for clinical use, which is justification for the performance of further studies to improve the understanding of the material's actions, before it can be used clinically. Thus, new clinical and experimental studies are required to evaluate the actual efficacy of these products. 
IL SCARDINI, research execution and article writing.

\section{REFERENCES}

1. Young A, Thrane PS, Saxegaard E, Jonski G, Rölla G. Effects of stannous fluoride toothpaste on erosion-like lesions: an in vivo study. Eur J Oral Sci. 2006;114(3):180-3. doi: 10.1111/j.16000722.2006.00354.x

2. Reis A, Higashi C, Loguercio AD. Re-anatomization of anterior eroded teeth by stratification with direct composite resin. J Esthet Restor Dent. 2009;21(5):304-16. doi: 10.1111/j.17088240.2009.00281.x

3. Ablal MA, Kaur JS, Cooper L, Jarad FD, Milosevic A, Higham $\mathrm{SM}$, et al. The erosive potential of some alcopops using bovine enamel: An in vitro study. J Dent. 2009;37(11):835-9. doi: 10.1016/j.jdent.2009.06.016

4. dos Santos PH, Consani S, Correr Sobrinho L, Coelho Sinhoreti MA. Effect of surface penetrating sealant on roughness of posterior composite resins. Am J Dent. 2003 Jun;16(3):197201.

5. Lee YK, Powers JM. Combined effects of staining substances on resin composites before and after surface sealant application. J Mater Sci Mater Med. 2007 Mai;18(5):685-91.

6. Rios D, Honório HM, Francisconi LF, Magalhães AC, de Andrade Moreira Machado MA, Buzalaf MA. In situ effect of an erosive challenge on different restorative materials and on enamel adjacent to these materials. J Dent. 2008;36(2):152-7. doi: 10.1016/j.jdent.2007.11.013

7. Ijima Y, Cai F, Shen P, Walker G, Reynolds C, Reynolds EC. Acid resistance of enamel subsurface lesions remineralized by a sugar-free chewing gum containing casein phosphopeptideamorphous calcium phosphate. Caries Res. 2004;38(6):551-6. doi: 10.1159/000080585

8. Reynolds EC, Cai F, Shen P, Walker GD. Retention in plaque and remineralization of enamel lesions by various forms of calcium in a mouthrinse or sugar-free chewing gum. J Dent Res. 2003;82(3):206-11.

9. Barbour ME, Shellis RP, Parker DM, Allen GC, Addy M. Inhibition of hydroxyapatite dissolution by whole casein: the effects of $\mathrm{pH}$, protein concentration, calcium, and ionic strength. Eur J Oral Sci. 2008 Out;116(5):473-8. doi: 10.1111/j.16000722.2008.00565.x.

10. Furtado JR, Valéria CF, Messias DCF, Turssi CP. Physicochemical aspects related to the erosive potential of acid beverages. RFO. 2010;15(3):325-330.

11. Carvalho FG, Brasil VL, Silva Filho TJ, Carlo HL, Santos RL, Lima BA. Protective effect of calcium nanophosphate and CPP-ACP agents on enamel erosion. Braz Oral Res. 2013;27(6):463-70. doi: 10.1590/S1806-83242013000600004

12. Corrêa FNP, Murakami C, Carvalho TS, Corrêa MSNP. Clinical diagnosis, prevention and treatment of dental erosion. Rev Assoc Paul Cir Dent. 2010;64(6):437-43.
MKN DIAS, research execution and article writing. MCC CASTRO and APA GUEDES, article writing. LM PEIXOTO, orientation to research and article writing.

13. Wegehaupt FJ, Attin T. The role of fluoride and casein phosphopeptide/amorphous calcium phosphate in the prevention of erosive/abrasive wear in an in vitro model using hydrochloric acid. Caries Res. 2010;44(4):358-63. doi: 10.1159/000316542

14. Rallan M, Chaudhary S, Goswami M, Sinha A, Arora R, Kishor A Effect of various remineralising agents on human eroded enamel of primary teeth. Eur Arch Paediatr Dent. 2013;14(5):313-8. doi: 10.1007/s40368-013-0085-9

15. Cai F, Manton DJ, Shen P, Walker GD, Cross KJ, Yuan Y, et al. Effect of addition of citric acid and casein phosphopeptideamorphous calcium phosphate to a sugar-free chewing gum on enamel remineralization in situ. Caries Res. 2007;41(5):377-83. doi: $10.1159 / 000104796$

16. Prestes $L$, Souza BM, Comar LP, Salomão PA, Rios D, Magalhães $A C$. In situ effect of chewing gum containing CPP-ACP on the mineral precipitation of eroded bovine enamel - a surface hardness analysis. J Dent. 2013;41(8):747-51. doi: 10.1016/j. jdent.2013.06.006

17. de Alencar CR, Magalhães AC, de Andrade Moreira Machado MA, de Oliveira TM, Honório HM, Rios D. In situ effect of a commercial CPP-ACP chewing gum on the human enamel initial erosion. J Dent. 2014;42(11):1502-7. doi: 10.1016/j. jdent.2014.08.008

18. Panich M, Poolthong S. The effect of casein phosphopeptideamorphous calcium phosphate and a cola soft drink on in vitro enamel hardness. J Am Dent Assoc. 2009 Abr;140(4):455-60. doi: 10.14219/jada.archive.2009.0195

19. Moretto MJ, Magalhães AC, Sassaki KT, Delbem AC, Martinhon CC. Effect of different fluoride concentrations of experimental dentifrices on enamel erosion and abrasion. Caries Res. 2010;44(2):135-40. doi: 10.1159/000302902

20. MI Paste [homepage da internet]. How to Apply [cited 2017 Abr 28]. Disponível em <http://www.mi-paste.com/index_MIP. php>.

21. Amaral CM, Miranda ME, Correa DS, Silva EM. Sodium fluoride and casein phosphopeptide-amorphous calcium phosphate cream plus sodium fluoride efficacy in preventing enamel erosion in a simulated oral environment study model. Indian J Dent Res. 2014;25(4):464-9. doi: 10.4103/0970-9290.142536

22. Schlueter N, HaraA, Shellis RP, Ganss C. Methods for measurement and Characterization of Erosion in Enamel and Dentine. Caries Res. 2011;45(1):13-23. doi: 10.1159/000326819

23. Zero DT. Etiology of dental erosion - extrinsic factors. Eur J Oral Sci. 1996;104(2):162-77. doi: 10.1111/j.1600-0722.1996. tb00065.x

24. West NX, Davies M, Amaechi BT. In vitro and in situ erosion models for evaluating tooth substance loss. Caries Res. 2011;45(1):43-52. doi: 10.1159/000325945

25. Young A, Tenuta LM. Initial erosion models. Caries Res. 
2011;(suppl 1):33-42. doi: 10.1159/000325943

26. Hall AF, Buchanan CA, Millett DT, Creanor SL, Strang R, Foye $\mathrm{RH}$. The effect of saliva on enamel and dentine erosion. J Dent. 1999;27(5):333-9.

27. Ionta FQ, Mendonça FL, Oliveira GC, Alencar CRB, Honório $H M$, Magalhães $A$, et al. In vitro assessment of artificial saliva formulations on initial enamel erosion remineralization. J Dent. 2014;42(2):175-9. doi: 10.1016/j.jdent.2013.11.009
28. JaeggiT, Lussi A. Prevalence, incidence and distribution of erosion. Monogr Oral Sci. 2006;20:44-65. doi: 10.1159/000093350

Received on: 24/3/2017

Final version resubmitted on: 5/7/2017

Approved on: 16/7/2017 